\title{
Relationships Between Urea Dilution Measurements and Body Weight and Composition of Lactating Dairy Cows
}

\author{
R. E. Agnew, ${ }^{1}$ T. Yan, ${ }^{1}$ W. J. McCaughey, ${ }^{1}$ J. D. McEvoy, ${ }^{2}$ D. C. Patterson, ${ }^{1}$ \\ M. G. Porter, ${ }^{1}$ and R. W. J. Steen ${ }^{1}$ \\ ${ }^{1}$ The Agricultural Research Institute of Northern Ireland, Hillsborough, BT26 6DR, UK \\ ${ }^{2}$ Veterinary Sciences Division, Stoney Road, Stormont, Belfast, BT4 3SB, UK
}

\begin{abstract}
The objective of the present study was to investigate the potential of the urea dilution technique, coupled with live animal measures to predict the body components of dairy cattle. The study involved 104 lactating Holstein-Friesian cows offered grass silage-based diets. Urea space volume (USV) was calculated from 2 collection periods of blood samples following infusion of urea at $12\left(\mathrm{USV}_{12}, \mathrm{~kg}\right)$ and $30\left(\mathrm{USV}_{30}, \mathrm{~kg}\right)$ min after infusion, and then as a proportion of live weight (LW) or empty body weight (EBW). All cows were slaughtered within $2 \mathrm{~d}$ of the USV trials. Large ranges existed in EBW and empty body concentrations of water, crude protein $(\mathrm{CP})$, lipid, ash, and gross energy (GE). The $\mathrm{USV}_{12}$ and $\mathrm{USV}_{30}$ were both positively related to LW, EBW, and empty body component weights. The $\mathrm{r}^{2}$ values for $\mathrm{USV}_{12}$ were greater than $\mathrm{USV}_{30}$. The $\mathrm{r}^{2}$ values in the relationships of EBW and empty body composition with USV, however, were smaller than those with LW. Nevertheless, the relationships were improved when both USV and LW were used as predictors, rather than using either alone. Adding milk yield and body condition score as supporting predictors to prediction equations using USV and LW data for EBW, lipid, and GE contents further improved the relationships $\left(r^{2}=0.93,0.66\right.$, and 0.77 , respectively). Internal evaluation of one-third of the present data using equations developed from two-thirds of the present data indicated that using USV, live weight, and other live animal variables as predictors, rather than using USV alone, considerably improved the prediction accuracy. It was concluded that USV can be used to predict body composition, but the relationships with USV were poorer than those with LW. The USV can only be used as a supporting variable to live weight for prediction of body components in lactating dairy cows.
\end{abstract}

(Key words: body composition, lactating dairy cow, prediction, urea space)

Received May 13, 2004.

Accepted March 19, 2005.

Corresponding author: T. Yan; e-mail: tianhai.yan@dardni.gov.uk.
Abbreviation key: $\mathbf{E B}=$ empty body, EBW = empty body weight, $\mathbf{G E}$ = gross energy, $\mathbf{L W}=$ live weight, $\mathbf{U S V}=$ urea space volume, $\mathbf{U S V}_{\mathbf{1 2}}=\mathrm{USV}$ at $12 \mathrm{~min}$ $(\mathrm{kg}) ; \mathbf{U S V}_{\mathbf{1 2 / L W}}$ or $\mathbf{U S V}_{\mathbf{1 2 / E B W}}=\mathrm{USV}$ at $12 \mathrm{~min}$ as a proportion of live weight or empty body weight $(\mathrm{kg} / \mathrm{kg})$; $\mathbf{U S V}_{\mathbf{3 0}}=\mathbf{U S V}$ at $30 \mathrm{~min}(\mathrm{~kg}) ; \mathbf{U S V}_{\mathbf{3 0 / L W}}$ or $\mathbf{U S V}_{\mathbf{3 0} / \mathbf{E B W}}=$ USV at $30 \mathrm{~min}$ as a proportion of live weight or empty body weight $(\mathrm{kg} / \mathrm{kg})$.

\section{INTRODUCTION}

Formulating rations for ruminant animals requires accurate estimates of nutrient requirements for maintenance, production, and other activities. Currently, the maintenance energy requirement in cattle is calculated as a proportion of total metabolic live weight $(\mathbf{L W})$ (AFRC, 1993; NRC, 2001). However, increasing evidence in the literature indicates that the energy expenditure for maintenance in animals mainly results from protein metabolism, whereas lipid metabolism requires relatively little energy (Agnew and Yan, 2000). This is supported by the findings of Birnie (1999) in which a significant negative relationship between fasting heat production and body condition was reported for dairy cows. Therefore, estimation of protein content in the live animal is a key factor in accurately quantifying the maintenance energy requirement.

A number of approaches to predict the body composition of live animals are found in the literature including use of the urea dilution technique. San Pietro and Rittenberg (1953) reported that urea seemed to meet all the requirements of a satisfactory tracer. Urea is nontoxic, nonforeign to the body, and shows an even and rapid distribution throughout total body water without any physiological effect. The urea dilution procedure has no detrimental effects on performance characteristics of feedlot steer cattle (Wells and Preston, 1998). For these reasons, in addition to being an easy and accurate measurement, urea is an ideal candidate tracer to estimate empty body (EB) water in vivo. Total body water volume (urea space volume; USV) can be estimated by dividing the total amount of urea infused by the increase in plasma urea concentration before 
and after infusion. Many studies have examined the relationships between USV and body composition in sheep, beef cows, and dry cows. Bartle et al. (1987) evaluated some of these equations and concluded that urea dilution was a valid estimator of body composition in growing-finishing cattle. The urea dilution technique could be a valuable research tool if multiple estimates of body composition over time are needed when the slaughtering of the animal is not desired (Wells and Preston, 1998). Little information exists, however, on the use of the urea dilution technique in lactating dairy cows, although Andrew et al. (1995) reported a poor relationship between EB water and USV data using 12 lactating and 9 prepartum dairy cows. More research using lactating dairy cows is needed.

During 1999, a series of slaughter trials were undertaken at the Agricultural Research Institute of Northern Ireland. One hundred four lactating dairy cows were subjected to urea dilution studies before slaughter. The objectives of the present study were to use these data to examine the relationships between USV and body composition and then develop prediction equations for body composition using USV and live animal data.

\section{MATERIALS AND METHODS}

\section{Animals}

The cattle used in the present study were HolsteinFriesian lactating dairy cows $(\mathrm{n}=104)$, subjected to compulsory slaughter in 1999, and selected from the herd at the Agricultural Research Institute of Northern Ireland. These cows had been subjected to a variety of nutritional and management regimens across a range of indoor feeding experiments before the slaughter, and remained in the same management and feeding regimens during the present study. All cows were housed in cubicle areas with box stalls and offered mixed diets of grass silages and concentrate supplements, with forage proportions in diets ranging proportionately from 0.30 to 0.60 (DM basis). Silages were made from perennial ryegrass dominant swards. Concentrates used included some of the following ingredients: barley, wheat, corn, corn gluten meal, molassed sugar-beet pulp, citrus pulp, molasses, soybean meal, and rapeseed meal, in addition to a vitamin and mineral supplement.

The cows were selected to represent a range of lactation numbers, BCS, genetic merit (low to high), stage of lactation (early to late), and LW (light to heavy) within the overall herd. Twenty-nine cows were in the first lactation, 32 in the second lactation, and the remaining animals were in their third or greater lactation. Milk production was recorded daily during lactation, and daily milk yield used in the present study was
Table 1. Animal data and urea space: means, standard deviations, and ranges.

\begin{tabular}{|c|c|c|c|c|}
\hline & Mean & SD & Minimum & Maximum \\
\hline \multicolumn{5}{|l|}{ General data } \\
\hline Condition score ${ }^{1}$ & 2.4 & 0.55 & 1.0 & 4.0 \\
\hline Milk yield, kg/d & 25.5 & 5.63 & 13.2 & 44.1 \\
\hline DIM & 149 & 70.0 & 23 & 472 \\
\hline Live weight, $\mathrm{kg}$ & 575 & 70.2 & 420 & 781 \\
\hline Empty BW, kg & 412 & 57.0 & 312 & 581 \\
\hline \multicolumn{5}{|c|}{ Concentrations of empty BW } \\
\hline Water, g/kg & 647 & 30.2 & 539 & 694 \\
\hline Gross energy, MJ/kg & 8.4 & 1.39 & 6.3 & 13.8 \\
\hline $\mathrm{CP}, \mathrm{g} / \mathrm{kg}$ & 186 & 7.9 & 157 & 200 \\
\hline Lipid, g/kg & 100 & 37.0 & 45 & 237 \\
\hline Ash, g/kg & 60 & 6.9 & 45 & 76 \\
\hline \multicolumn{5}{|l|}{ Urea space $^{2}$} \\
\hline $\mathrm{USV}_{12}, \mathrm{~kg}$ & 308 & 44.8 & 193 & 408 \\
\hline $\mathrm{USV}_{12 / \mathrm{LW}}, \mathrm{g} / \mathrm{kg}$ & 549 & 55.0 & 426 & 653 \\
\hline $\mathrm{USV}_{12 / \mathrm{EBW}}, \mathrm{g} / \mathrm{kg}$ & 752 & 79.6 & 594 & 918 \\
\hline $\mathrm{USV}_{30}, \mathrm{~kg}$ & 382 & 61.9 & 257 & 575 \\
\hline $\mathrm{USV}_{30 / \mathrm{LW}}, \mathrm{g} / \mathrm{kg}$ & 680 & 79.0 & 481 & 966 \\
\hline $\mathrm{USV}_{30 / \mathrm{EBW}}, \mathrm{g} / \mathrm{kg}$ & 933 & 121.6 & 662 & 1456 \\
\hline
\end{tabular}

${ }^{1}$ Body condition was scored on a scale from 1 (very thin) to 5 (very fat).

${ }^{2} \mathrm{USV}_{12}, \mathrm{USV}_{12 / \mathrm{LW}}$, or $\mathrm{USV}_{12 / \mathrm{EBW}}=$ Urea space volume at $12 \mathrm{~min}$, as a proportion of live weight or empty BW; $\mathrm{USV}_{30}, \mathrm{USV}_{30 / \mathrm{LW}}$, or $\mathrm{USV}_{30 / \mathrm{EBW}}=$ urea space volume at $30 \mathrm{~min}$, as a proportion of live weight or empty BW.

averaged from the week before slaughter. The LW and BCS were recorded 3 or $4 \mathrm{~d}$ before slaughter. Body condition of each cow was scored using the method described by Mulvenny (1977), having 5 categories from 1 (very thin) to 5 (very fat). Live animal data are presented in Table 1.

\section{Urea Dilution Measurements}

Urea dilution trials were performed on all 104 cows. Before the trials, the cows were weighed and a $10-\mathrm{mL}$ blood sample was collected from the coccygeal vein of each cow to determine plasma urea concentration. Then, a urea solution was administered over a 3-min period through a $1.6-\mathrm{mm} \times 600-\mathrm{mm}$ polyethylene catheter, inserted into a jugular vein. The solution contained $20 \mathrm{IU} / \mathrm{mL}$ of reagent grade urea (Sigma-Aldrich Chemical Co., Tallaght, Dublin, Ireland) dissolved in $9 \mathrm{~g} / \mathrm{L}$ of isotonic saline (Baxter Healthcare Ltd., Thetford, UK). The volume injected was calculated to provide $130 \mathrm{mg}$ of urea per kg of LW. After infusion, the catheter was flushed with saline and then removed. Blood samples $(10 \mathrm{~mL})$ were collected from the coccygeal vein at 12 and 30 min after the mean infusion time and stored in plasma lithium heparin push-up tubes. Blood samples were placed immediately in an ice bath and then centrifuged at $1890 \times g$ for $15 \mathrm{~min}$. A 5-mL plasma subsample was removed from each sample and immediately frozen 
at $-20^{\circ} \mathrm{C}$ for the subsequent determination of plasma urea concentration.

Urea concentration in plasma was analyzed by a modification of the carbamido-diacetyl method on a Technicon AA2 Autoanalyzer (method 339-01, Technicon Industrial Systems, Tarrytown, NY) based on the method of Marsh et al. (1965). The USV was calculated by dividing the precise quantity of urea infused by the difference in plasma urea concentration before and after infusion at $12\left(\mathbf{U S V}_{\mathbf{1 2}}, \mathrm{kg}\right)$ or $30\left(\mathbf{U S V}_{\mathbf{3 0}}, \mathrm{kg}\right) \mathrm{min}$. The USV was also expressed as a proportion of $\mathrm{LW}\left(\mathbf{U S V}_{\mathbf{1 2} / \mathrm{LW}}\right.$, or $\left.\mathbf{U S V}_{\mathbf{3 0 / L W}}, \mathrm{kg} / \mathrm{kg}\right)$ and empty BW (EBW; $\mathbf{U S V}_{\mathbf{1 2} / \mathbf{E B W}}$ or $\mathbf{U S V}_{\text {30/EBW }}, \mathrm{kg} / \mathrm{kg}$ ), respectively. All USV data are presented in Table 1.

\section{Body Composition Analysis}

All cows were slaughtered within $2 \mathrm{~d}$ of the USV trials and all procedures for the determination of body composition were undertaken during $2 \mathrm{wk}$. The fetalplacental unit and associated fluids were removed from pregnant cows after slaughter. The exsanguinated bodies of the cows were then divided into 8 components, namely, hide, feet, udder, head (including spinal cord and thymus), alimentary tract (excluding all contents except contents of omasum), urogenital tract, pluck (trachea, lungs, heart, diaphragm, liver, kidneys, and tail), and carcass. Perinephric and retroperitoneal fat were included with alimentary tract. The weight of each component was recorded at the time of collection and all components were stored at $-20^{\circ} \mathrm{C}$.

Each component was subsequently shredded and minced while in the frozen state and representative samples taken for determination of DM. Representative samples of each component were collected for determination of $\mathrm{N}$, total lipid, ash, and energy concentrations. The DM, N, and ash concentrations were determined as detailed in AOAC (1996). Total lipid was determined as described by Bligh and Dyer (1959). Energy concentration was determined in an adiabatic bomb calorimeter using a modification of the method of Porter (1992) for all components except the feet and hide components. For these 2 components, energy concentration was estimated by applying constant energy values of 23.85 and $39.75 \mathrm{MJ} / \mathrm{kg}$ to $\mathrm{CP}$ and total lipid respectively (Brouwer, 1965). The EBW (LW minus weights of gut contents and fetal-placental unit) and contents of CP, lipid, ash, energy, and EB water are presented in Table 1.

\section{Statistical Analyses}

Prediction equations for EBW, EB composition, and energy content were developed using either USV or LW as a single predictor in the linear regression (equation [i]) or using both USV and LW together with other animal factors (e.g., milk yield, BCS, and parity) as predictors in multiple regression (equation [ii]). A stepwise multiple regression technique was used to develop multiple prediction equations and the technique automatically selects the best and significant predictors to fit the prediction equations.

$$
\begin{gathered}
y=a+b x \\
y=a+b 1 x 1+b 2 x 2+\ldots+b n x n
\end{gathered}
$$

The preceding equations were fitted to the following equations, respectively, to remove the effect of stage of lactation for the linear equations or the effect of stage of lactation or parity for the multiple equations,

$$
\begin{gathered}
y=a i+b 1 x 1 \\
y=a i+b 1 x 1+b 2 x 2 \ldots+b n x n
\end{gathered}
$$

where ai represents the effect of stage of lactation or parity i for $\mathrm{i}=1$ to $3, \mathrm{x} 1, \mathrm{x} 2, \ldots$ and $\mathrm{xn}$ are the $\mathrm{x}$-variables and $b 1, b 2, \ldots$ and bn are their regression coefficients. In the present study, the stage of lactation was categorized as 3 stages (stages 1,2 , and 3 representing 1 to 75,76 to 150 , and >150 DIM, respectively). Parity was also divided into 3 categories (1, 2, and $3+$ ). The statistical program used in the present study was Genstat 6.1, 6th edition (Lawes Agricultural Trust, Rothamsted, UK).

\section{RESULTS}

\section{Data on Animals and Urea Space}

Means, standard deviations, and ranges of data and USV for the 104 cows are presented in Table 1. The dairy cows used represented a large range in lactation numbers (1 to 7 ), BCS (1 to 4), stage of lactation (23 to 472 DIM and milk yield ranging from 13.2 to $44.1 \mathrm{~kg} /$ d), and LW (420 to $781 \mathrm{~kg}$ ). The large range in the above variables also produced great variations in EBW and EB composition.

A large range occurred in $\mathrm{USV}_{12}$ (193 to 408 , mean 308 , SD $44.8 \mathrm{~kg}$ ). Similarly, USV $12 / \mathrm{Lw}$ ranged from 426 to $653 \mathrm{~g} / \mathrm{kg}\left[549 \pm 55.0\right.$ (SD)] and $\mathrm{USV}_{12 / \mathrm{EBW}}$ from 594 to $918 \mathrm{~g} / \mathrm{kg}[752 \pm 9.6$ (SD)]. Similar patterns were recorded for $\mathrm{USV}_{30}, \mathrm{USV}_{30 / \mathrm{LW}}$, and $\mathrm{USV}_{30 / \mathrm{EBW}}$, although all values were proportionally greater than $\mathrm{USV}_{12}$ data.

\section{Relationships Between Urea Space and Animal Data}

In general, the relationships between $\mathrm{USV}_{12}$ or $\mathrm{USV}_{30}$ and animal variables (parity, BCS, milk yield, LW, 
Table 2. Linear relationships between urea space or live weight and empty BW or its components (kg or $\mathrm{MJ}$; values in parentheses are SE). ${ }^{1,2}$

\begin{tabular}{|c|c|c|c|c|}
\hline Equation & & $\mathrm{r}^{2}$ & $\mathrm{SE}$ & $\begin{array}{l}\text { Equation } \\
\text { no. }\end{array}$ \\
\hline \multirow[t]{3}{*}{ EBW } & $=0.921_{(0.082)}\left[\mathrm{USV}_{12}\right]+133.7_{(27.2)}$ & 0.58 & 37.4 & $1 \mathrm{a}$ \\
\hline & $=0.609_{(0.066)}\left[\mathrm{USV}_{30}\right]+186.7_{(27.5)}$ & 0.49 & 41.4 & $1 \mathrm{~b}$ \\
\hline & $=0.761_{(0.028)}[\mathrm{LW}]-26.0_{(16.2)}$ & 0.88 & 19.9 & $1 \mathrm{c}$ \\
\hline \multirow[t]{3}{*}{$\mathrm{CP}$} & $=0.157_{(0.013)}\left[\mathrm{USV}_{12}\right]+28.7_{(4.4)}$ & 0.61 & 6.0 & $2 \mathrm{a}$ \\
\hline & $=0.107_{(0.010)}\left[\mathrm{USV}_{30}\right]+36.6_{(4.3)}$ & 0.54 & 6.5 & $2 \mathrm{~b}$ \\
\hline & $=0.124_{(0.005)}[\mathrm{LW}]+4.9_{(3.0)}$ & 0.85 & 3.6 & $2 \mathrm{c}$ \\
\hline \multirow[t]{3}{*}{ Lipid } & $=0.208_{(0.041)}\left[\mathrm{USV}_{12}\right]-19.5_{(13.0)}$ & 0.25 & 18.5 & $3 a$ \\
\hline & $=0.138_{(0.030)}\left[\mathrm{USV}_{30}\right]-7.8_{(12.1)}$ & 0.21 & 18.9 & $3 \mathrm{~b}$ \\
\hline & $=0.199_{(0.022)}[\mathrm{LW}]-71.9_{(12.9)}$ & 0.44 & 15.8 & $3 \mathrm{c}$ \\
\hline \multirow[t]{3}{*}{ Ash } & $=0.062_{(0.007)}\left[\mathrm{USV}_{12}\right]+5.7_{(2.3)}$ & 0.48 & 3.2 & $4 \mathrm{a}$ \\
\hline & $=0.038_{(0.006)}\left[\mathrm{USV}_{30}\right]+10.6_{(2.3)}$ & 0.35 & 3.5 & $4 \mathrm{~b}$ \\
\hline & $=0.047_{(0.004)}[\mathrm{LW}]-2.6_{(2.2)}$ & 0.59 & 2.8 & $4 \mathrm{c}$ \\
\hline \multirow[t]{3}{*}{ Gross energy } & $=12.0_{(1.8)}\left[\mathrm{USV}_{12}\right]-85_{(584)}$ & 0.35 & 819 & $5 \mathrm{a}$ \\
\hline & $=8.0_{(1.4)}\left[\mathrm{USV}_{30}\right]+567_{(550)}$ & 0.31 & 847 & $5 \mathrm{~b}$ \\
\hline & $=10.9_{(0.9)}[\mathrm{LW}]-2775_{(527)}$ & 0.58 & 648 & $5 c$ \\
\hline \multirow[t]{3}{*}{ Water } & $=0.490_{(0.044)}\left[\mathrm{USV}_{12}\right]+116.6_{(14.0)}$ & 0.57 & 19.8 & $5 \mathrm{a}$ \\
\hline & $=0.324_{(0.035)}\left[\mathrm{USV}_{30}\right]+144.9_{(14.2)}$ & 0.48 & 21.9 & $6 \mathrm{~b}$ \\
\hline & $=0.386_{(0.018)}[\mathrm{LW}]+43.2_{(10.3)}$ & 0.82 & 12.6 & $6 c$ \\
\hline
\end{tabular}

${ }^{1}$ Effect of stage of lactation on these relationships was removed and all relationships were significant $(P$ $<0.001$ )

${ }^{2} \mathrm{EBW}=$ Empty body weight $(\mathrm{kg}) ; \mathrm{LW}=$ live weight $(\mathrm{kg}) ; \mathrm{USV}_{12}$ and $\mathrm{USV}_{30}=$ urea space volume at 12 and $30 \mathrm{~min}(\mathrm{~kg})$.

EBW, and EB components) were all positive $(P<0.05)$, with the exception of EB water concentration, which had a negative relationship with $\operatorname{USV}_{12}(P<0.001)$ or $\mathrm{USV}_{30}(P<0.01)$. Both $\mathrm{USV}_{12}$ and $\mathrm{USV}_{30}$ were related $(P<0.001)$ to parity, LW, EBW, total amounts of CP, lipid, ash, gross energy (GE), and EB water, whereas their relationships with component contents as a proportion of LW or EBW were less significant. For example, there were no relationships between $\mathrm{USV}_{12}$ or $\mathrm{USV}_{30}$ and CP concentration in LW or EBW or EB ash concentration. Significances were only at the $P<0.05$ level for the relationships between $\mathrm{USV}_{30}$ and lipid or GE concentration in LW or EBW, and at the 0.01 level for the relationships between $\mathrm{USV}_{12}$ and lipid or GE concentration in LW or EBW.

There was no significant relationship between $\mathrm{USV}_{30 /}$ LW and any variable examined in the present study, but the relationship between $\mathrm{USV}_{12 / \mathrm{LW}}$ and BCS or LW was significant $(P=0.05)$. Relationships improved, however, when using $\mathrm{USV}_{12 / \mathrm{EBW}}$ and $\mathrm{USV}_{30 / \mathrm{EBW}}$, rather than $\mathrm{USV}_{12 / \mathrm{LW}}$ and $\mathrm{USV}_{30 / \mathrm{LW}}$. For example, $\mathrm{USV}_{12 / \mathrm{EBW}}$ and $\mathrm{USV}_{30 / \mathrm{EBW}}$ both had negative $(P<0.05)$ relationships with EBW, lipid, and GE contents as a proportion of LW and EBW, and total amounts of lipid and GE, respectively. Both $\mathrm{USV}_{12 / \mathrm{EBW}}$ and $\mathrm{USV}_{30 / \mathrm{EBW}}$ positively $(P$ $<0.001$ ) related to $\mathrm{CP}$ and $\mathrm{EB}$ water contents as a proportion of EBW. In addition, $\mathrm{USV}_{12 / \mathrm{EBW}}$ had a negative relationship with BCS $(P<0.001)$, and $\mathrm{USV}_{30 / \mathrm{EBW}}$ had a positive relationship with milk yield $(P<0.05)$ and a negative relationship with DIM $(P<0.05)$.

\section{Prediction Equations for Empty Body Composition}

The prediction equations for EBW and its components using $\mathrm{USV}_{12}, \mathrm{USV}_{30}$, or LW as the sole predictor (effect of stage of lactation removed) are presented in Table 2. The relationships between $\mathrm{USV}_{12}$ and EBW, $\mathrm{CP}$, and EB water contents also are presented in Figure 1. All relationships (equations [1a] to [6c] in Table 2) were significant $(P<0.001)$. In general, the prediction equations using $\mathrm{USV}_{12}$ as the predictor had greater $\mathrm{r}^{2}$ values and smaller standard errors than using $\mathrm{USV}_{30}$, whereas using LW as the predictor greatly improved the relationships compared with using $\mathrm{USV}_{12}$ or $\mathrm{USV}_{30}$. Within each predictor, the relationships for prediction of EBW and CP content were the strongest, and for lipid content, the poorest.

Because the relationships between EBW/EB components and $\mathrm{USV}_{12}$ were stronger than those using $\mathrm{USV}_{30}$, only $\mathrm{USV}_{12}, \mathrm{USV}_{12 / \mathrm{LW}}$, and $\mathrm{USV}_{12 / \mathrm{EBW}}$ were then used as primary predictors to develop multiple prediction equations (Table 3 ). In the majority of these equations, the effect of stage of lactation or parity was removed when significant $(P<0.05)$. The relationships presented in Table 3 were all significant $(P<0.001)$ and each predictor had an effect on the relationship $(P<0.05)$. Using both USV and LW as predictors, rather than using either alone, for the prediction of EBW and $\mathrm{EB}$ components improved the relationships. For example, the $\mathrm{r}^{2}$ values were increased to $0.90,0.89,0.50,0.63$, 0.66, and 0.85 for EBW, CP, lipid, ash, GE and EB 

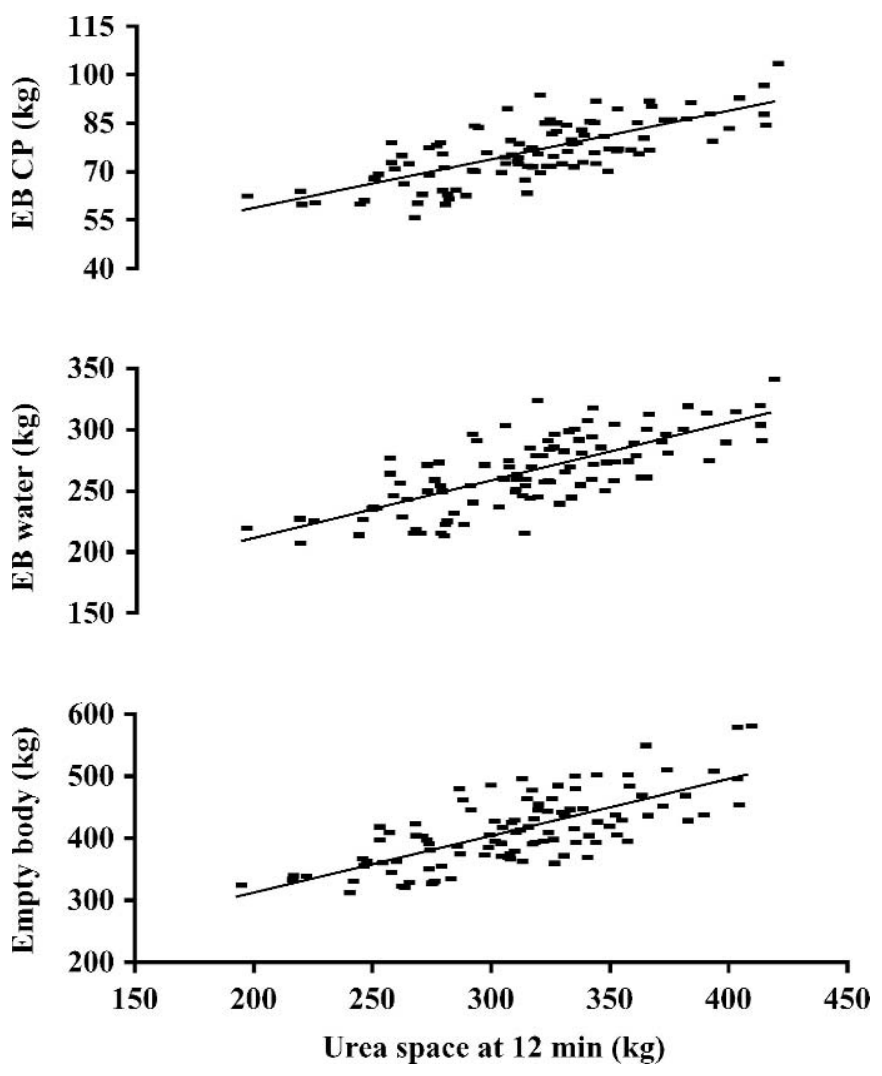

Figure 1. Relationships between urea space volume at $12 \mathrm{~min}$ and empty body (EB), CP, and water contents in empty body of lactating dairy cows $(\mathrm{n}=104)$. water (equations [7a], [8], [9a], [10a], [11a], and [12]), respectively, when using both USV and LW as predictors, instead of using LW alone (equations [1c], [2c], [3c], [4c], [5c], and [6c]; $\mathrm{r}^{2}=0.88,0.85,0.44,0.59,0.58$, and 0.82 , respectively). The corresponding standard errors were reduced proportionately by $0.11,0.13,0.05$, $0.04,0.09$, and 0.06 , respectively. Each inclusion of an additional predictor (parity, milk yield, or BCS) further increased $\mathrm{r}^{2}$ and reduced standard error for EBW, lipid, ash, and energy contents. Therefore, $r^{2}$ values increased to 0.93 for EBW (equation [7d]), 0.66 for lipid (equation [9d]), 0.68 for ash (equation [10b]), and 0.77 for GE (equation [11d]). The increase in $\mathrm{r}^{2}$ values was, proportionately, 0.50 for lipid (equation [9d] vs. [3c]) and 0.33 for GE (equation [11d] vs. [5c]), when derived from the multiple equation (USV, LW, milk yield, and BCS as predictors), rather than from the linear equation (LW as the predictor).

\section{Internal Evaluation}

Internal evaluation was undertaken by dividing the present data into 2 subsets, one-third $(\mathrm{n}=35)$ and twothirds $(\mathrm{n}=69)$ of data, according to the range of $\mathrm{USV}_{12}$. The two-thirds were used to develop the similar equations to those presented in Tables 2 and 3 . These new equations (Table 4) were then evaluated using one-third of the original data.

Prediction accuracy of relationships was examined using the mean-square prediction error (MSPE) as described by Rook et al. (1990). The MSPE is defined as equation $[\mathrm{v}]$ and can be regarded as the sum of 3 components (equation [vi]).

Table 3. Multiple regression equations for empty BW and its components (kg or MJ) using urea space and live weight with other variables (values in parentheses are SE). ${ }^{1,2}$

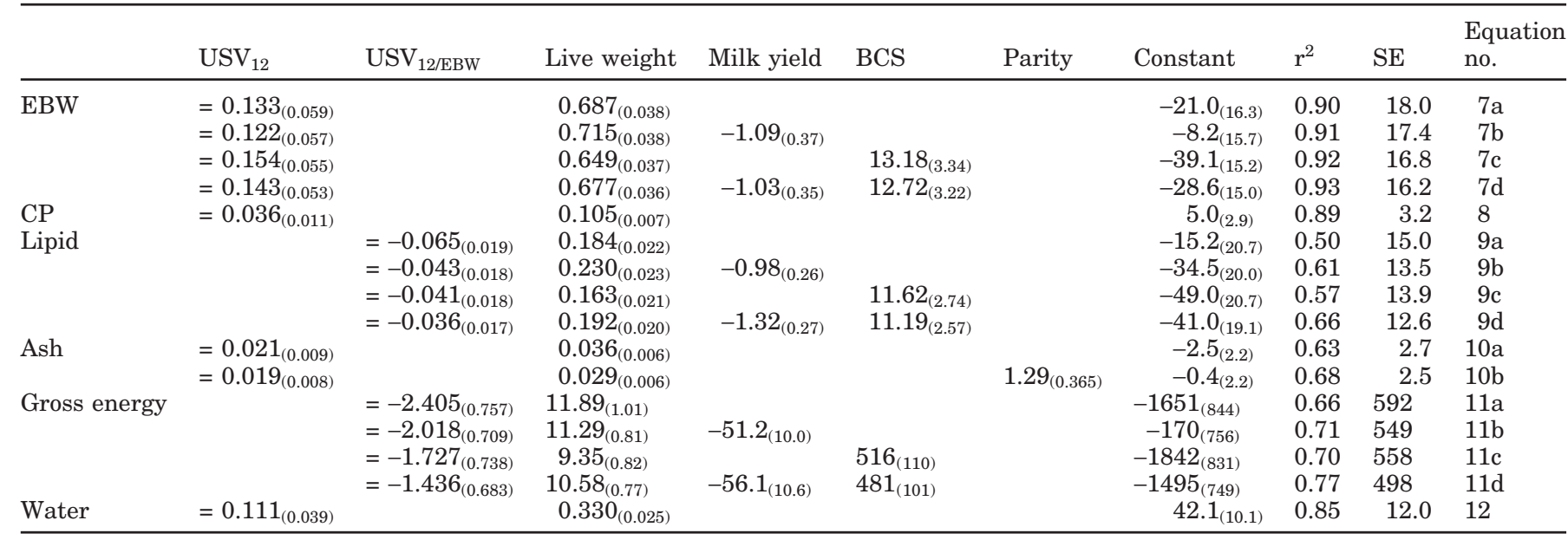

${ }^{1}$ Effect of stage of lactation or parity was removed in these relationships.

${ }^{2} \mathrm{EBW}=$ Empty BW $(\mathrm{kg}) ; \mathrm{LW}=$ live weight $(\mathrm{kg}) ; \mathrm{USV}_{12}$ or $\mathrm{USV}_{12 / \mathrm{EBW}}=$ urea space volume at $12 \mathrm{~min}(\mathrm{~kg})$ or urea space volume at $12 \mathrm{~min}$ as a proportion of $\mathrm{EBW}(\mathrm{g} / \mathrm{kg})$. 
Table 4. Internal evaluation showing prediction equations for empty BW and its components (kg or MJ) developed using two thirds of the present data (the values in parentheses are SE). ${ }^{1,2}$

\begin{tabular}{|c|c|c|c|c|c|c|c|c|c|}
\hline & $\mathrm{USV}_{12}$ & $\mathrm{USV}_{12 / \mathrm{EBW}}$ & Live weight & Milk yield & BCS & Constant & $\mathrm{r}^{2}$ & SE & Eq. no \\
\hline \multirow{2}{*}{ EBW } & $=0.157_{(0.069)}$ & & $0.680_{(0.047)}$ & & & $-25.7_{(22.3)}$ & 0.89 & 18.4 & $13 \mathrm{~b}$ \\
\hline & $=0.163_{(0.062)}$ & & $0.666_{(0.046)}$ & $-1.07_{(0.33)}$ & $17.94_{(4.02)}$ & $-39.0_{(19.0)}$ & 0.91 & 16.5 & $13 \mathrm{c}$ \\
\hline $\mathrm{CP}$ & $=0.037_{(0.013)}$ & & $0.104_{(0.009)}$ & & & $5.4_{(4.1)}$ & 0.86 & 3.4 & $14 \mathrm{~b}$ \\
\hline \multirow[t]{2}{*}{ Lipid } & $=0.174_{(0.047)}$ & & & & & $-10.5_{(15.0)}$ & 0.24 & 17.2 & $15 \mathrm{a}$ \\
\hline & & $=-0.049_{(0.021)}$ & $0.180_{(0.026)}$ & & & $-22.7_{(23.9)}$ & 0.53 & 13.7 & $15 \mathrm{~b}$ \\
\hline Ash & $=0.018_{(0.009)}$ & & $0.036_{(0.007)}$ & & & $-1.7_{(2.8)}$ & 0.58 & 2.6 & $16 \mathrm{~b}$ \\
\hline \multirow[t]{3}{*}{ Gross energy } & $=10.40_{(2.20)}$ & & & & & $320_{(693)}$ & 0.32 & 790 & $17 \mathrm{a}$ \\
\hline & & $=-2.042_{(0.889)}$ & $10.30_{(1.07)}$ & & & $-811_{(1005)}$ & 0.66 & 566 & $17 \mathrm{~b}$ \\
\hline & & $=-2.108_{(0.780)}$ & $11.63_{(1.00)}$ & $-48.60_{(10.10)}$ & & $-347_{(869)}$ & 0.72 & 509 & $17 \mathrm{c}$ \\
\hline \multirow[t]{2}{*}{ Water } & $=0.417_{(0.058)}$ & & & & & $136.7_{(16.9)}$ & 0.55 & 19.7 & $18 \mathrm{a}$ \\
\hline & $=0.135_{(0.046)}$ & & $0.325_{(0.032)}$ & & & $37.0_{(13.6)}$ & 0.83 & 12.4 & $18 \mathrm{~b}$ \\
\hline
\end{tabular}

${ }^{1}$ Effect of stage of lactation or parity was removed in these relationships.

${ }^{2} \mathrm{EBW}=\mathrm{Empty} \mathrm{BW}(\mathrm{kg}) ; \mathrm{LW}=$ live weight $(\mathrm{kg}) ; \mathrm{USV}_{12}$ or $\mathrm{USV}_{12 / \mathrm{EBW}}=$ urea space volume at $12 \mathrm{~min}(\mathrm{~kg})$ or urea space volume at $12 \mathrm{~min}$ as a proportion of EBW $(\mathrm{g} / \mathrm{kg})$.

$$
\begin{gathered}
\text { MSPE }=\frac{1}{n} \sum(P-A)^{2} \\
\mathrm{MSPE}=(\bar{P}-\bar{A})^{2}+\mathrm{S}_{\mathrm{P}}{ }^{2}(1-\mathrm{b})^{2}+\mathrm{S}_{\mathrm{A}}{ }^{2}\left(1-\mathrm{r}^{2}\right)
\end{gathered}
$$

where $\mathrm{P}$ or $\mathrm{A}$ is predicted or actual data; $\mathrm{n}$ is the number of pairs of values of $\mathrm{P}$ and A compared; $\bar{P}$ and $\bar{A}$ are the mean of $\mathrm{P}$ and $\mathrm{A} ; \mathrm{S}_{\mathrm{P}}{ }^{2}$ and $\mathrm{S}_{\mathrm{A}}{ }^{2}$ are the variances of $\mathrm{P}$ and $\mathrm{A} ; \mathrm{b}$ and $\mathrm{r}$ are the slope and correlation coefficient, respectively, of the linear regression of $\mathrm{P}$ on $\mathrm{A}$. The 3 components are thus due to mean bias $(\bar{P}-\bar{A})$, line bias (the deviation of the slope), and random variation of the slope. Mean prediction error (MPE), rather than MSPE, was used to describe the prediction accuracy $(\mathrm{MPE}=\sqrt{M S P E} / \bar{A})$.

Results presented in Table 5 indicated that the mean predicted EBW and EB components were similar to actual data, with the exception of [15c], which underpredicted lipid contents by proportionately 0.09 . The vast majority of prediction error was derived from random variation when using $\mathrm{USV}_{12}$ alone to predict EBW and EB components. Addition of LW, milk yield, and BCS as secondary predictors marginally increased the error of random variation as a proportion of MSPE, with the exception of prediction of ash for which adding LW substantially increased this parameter from 0.82 to 0.97 (equation [16a] vs. [16b]). In contrast, MPE values for EBW and EB components were substantially reduced and $\mathrm{r}^{2}$ values in the relationships between predicted and actual data increased when using multiple equations, rather than using $\mathrm{USV}_{12}$ as single predictor.

Residual plots also were used to evaluate prediction accuracy by plotting the predicted data (x-axis) against the corresponding difference (y-axis) between predicted and actual values. The results are presented in Figures 2 and 3. The residual plots for prediction of EBW and $\mathrm{EB}$ components using $\mathrm{USV}_{12}$ as a single predictor were much scattered (equations [13a], [14a], [15a], [16a], [17a], and [18a]), whereas the plots using multiple prediction equations were distributed relatively around the zero lines (equations [13b], [13c], [14b], [15b], [15c], [16b], [17b], [17c], and 18b). The SD values and the ranges for the residual differences (predicted - actual data) (Table 5) were in accordance with MPE and $r^{2}$ values, i.e., the $S D$ values and the ranges with multiple equations were smaller than those using $\mathrm{USV}_{12}$ as a single predictor.

It is concluded that $\mathrm{USV}_{12}$ can be used to predict EBW and EB components of lactating dairy cows, but the prediction accuracy is substantially improved when $\mathrm{USV}_{12}$ is used with LW and other live animal variables.

\section{DISCUSSION}

The lactating dairy cows $(\mathrm{n}=104)$ used in the present study represented a large range in lactation number, stage of lactation, BCS, genetic merit, and LW. No comparable data exist in the literature on the prediction of body condition of lactating dairy cows using USV data. Although a few studies using nonlactating (Jones et al., 1982; Bartle et al., 1983) and lactating dairy cows (Andrew et al., 1995) exist, numbers of cows used in those studies ( $\mathrm{n}=25,11$, and 21 , respectively) were much smaller than those used in the present study.

The dilution technique is based on the principle that there is a relatively constant relationship between EB water and other body components (Reid et al., 1955). 
Table 5. Internal evaluation of prediction equations, developed from two-thirds of the present data, using one-third of present data.

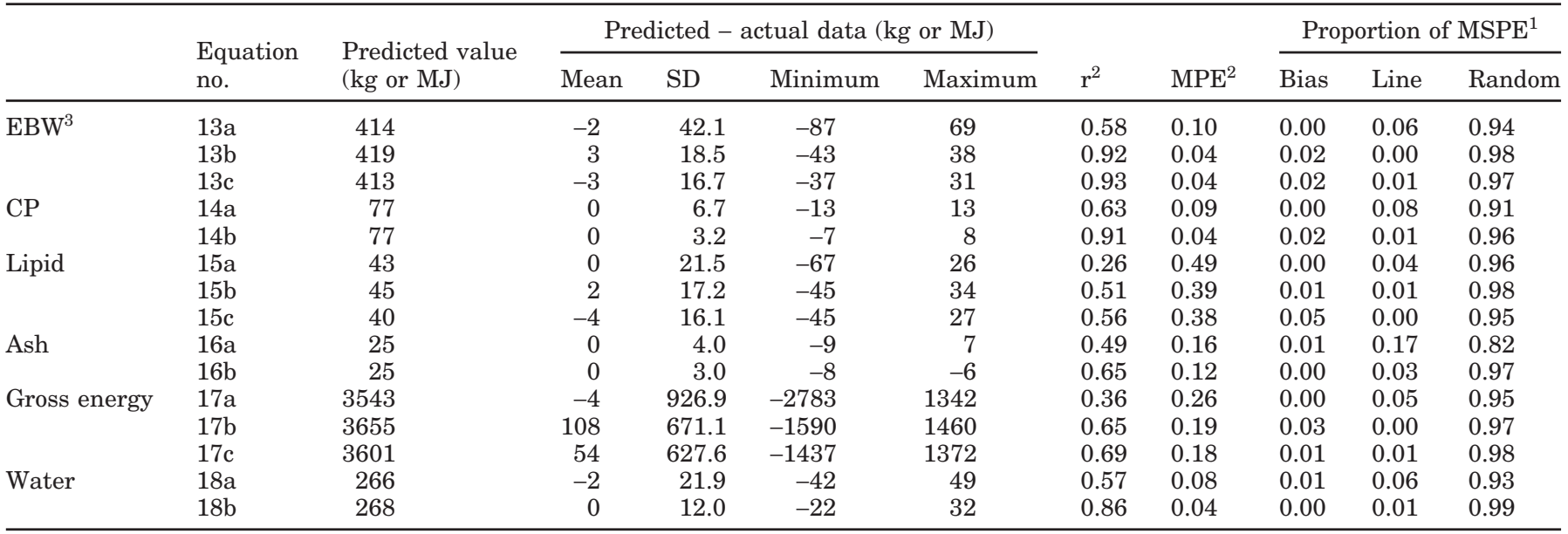

${ }^{1} \mathrm{MSPE}=$ Mean square prediction error.

${ }^{2} \mathrm{MPE}=$ Mean prediction error $(=\sqrt{M S P E} / \bar{A} ; \bar{A}=$ actual mean value $)$.

${ }^{3} \mathrm{EBW}=$ Empty BW.

Urea dilution is adopted to estimate the EB water contents (USV) and then it is used to predict body components of fat and protein. In the present study, USV was determined at 2 times (blood samples were collected 12 and 30 min after urea infusion). Correlation coefficients were generally greater for the linear relationships of animal data with $\mathrm{USV}_{12}$ than with $\mathrm{USV}_{30}$. The multiple prediction equations with only $\mathrm{USV}_{12}, \mathrm{USV}_{12 / \mathrm{LW}}$, and $\mathrm{USV}_{12 / \mathrm{EBW}}$ were thus reported in the present study. Kock and Preston (1979) collected blood samples in a series of time intervals (6 to $18 \mathrm{~min}$ ) after urea infusion in 113 beef steers. They reported that USV determined at 12 min was best for estimating body composition.

Using the urea dilution technique, many studies reported a significant relationship between USV and EB water, protein or fat content in beef cattle (Kock and Preston, 1979; Bennett et al., 1982; Bartle et al., 1987; Hammond et al., 1988) and in dairy steers (Hammond et al., 1990). Rule et al. (1986) used 28 beef steers from 6 to $18 \mathrm{mo}$ of age to validate the prediction equations for EB water previously reported (Preston and Kock, 1973; Meissner et al., 1980; Hammond et al., 1984). It was concluded that these equations were valid for prediction of EB water proportions, but most equations were not valid to predict EB water volume (Rule et al., 1986). Bartle et al. (1987) used 54 growing beef cattle to validate a range of equations for prediction of $\mathrm{EB}$ water, protein, and fat contents, which were reported in the former 3 studies and also by Jones et al. (1982) and Rule et al. (1986). The conclusion of this validation was that USV seemed to be a valid estimator of body composition in growing-finishing cattle (Bartle et al., 1987). In addition, there are no detrimental effects of the urea dilution procedure on performance characteristics of feedlot cattle (Wells and Preston, 1998). Further, they reported that USV might accurately evaluate body composition of beef cattle of different types.

The variation in body composition of dairy cows is much greater than that of market weight beef cattle. Variation in body composition of beef cattle mainly results from physiological state (growing vs. finishing) when they are of the same breed and offered the same diets ad libitum. For dairy cows within breed, however, many animal factors can influence body composition, including pregnancy and lactation status, stage of lactation, genetic merit, and parity. For example, although variations among cows existed in the present study, lipid proportion over EBW differed from 45 to $236 \mathrm{~g} / \mathrm{kg}$ and the corresponding GE concentration from 6.0 to 13.5 MJ per kg of EBW. In contrast, mean water (656), lipid (100), and CP (176) proportions over EBW (g/kg) in the present study were similar to those reported in early and late lactating Holstein cows $(630,138$, and 179; Andrew et al., 1995) and in Holstein steers (661, 101, and 185; Hammond et al., 1990).

Effects of the many animal factors on body composition of lactating dairy cow within breed make it difficult to produce prediction equations for body composition using the USV technique. For example, Jones et al. (1982) reported a significant relationship between USV and fat or protein content $\left(\mathrm{r}^{2}=0.54\right.$ or 0.55$)$ using 25 nonpregnant and nonlactating Holstein cows. In contrast, Andrew et al. (1995) did not find any significant relationship between USV and EB water content when 8 prepartum, 7 early lactation, and 6 late lactation Holstein cows were used. These differences likely oc- 

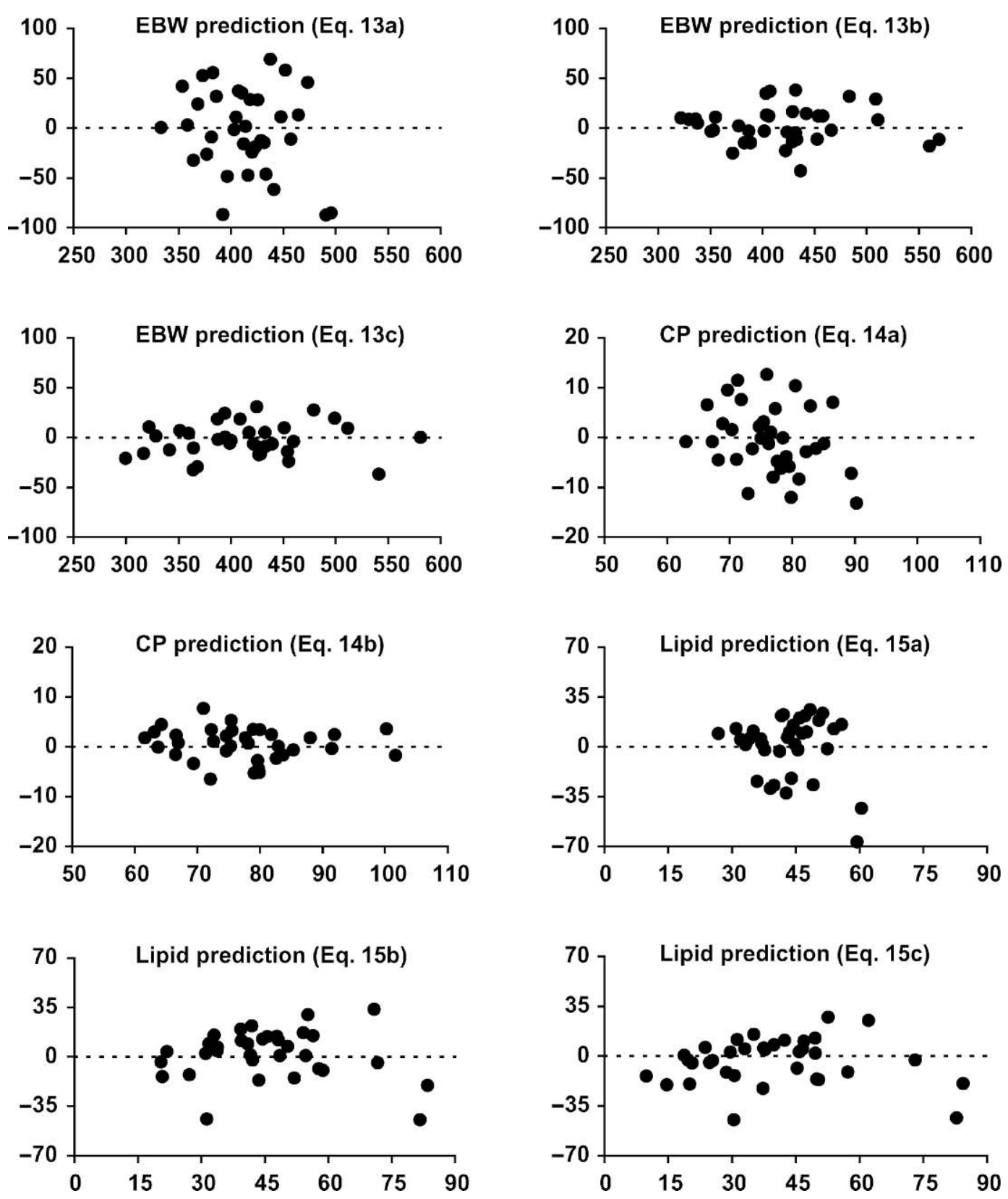

Figure 2. Predicted (x-axis) vs. residual (predicted - actual, y-axis) empty BW (EBW), CP, and lipid contents (kg). Internal evaluation of prediction equations developed from two-thirds of present data using one-third of the present data.

curred because the latter study had relatively few observations, but a large variation in physiological states. Compared with the latter study, we used 5 times as many cows and did not include nonlactating cows. When stage of lactation (early, mid, and late) was statistically removed, the present study recorded a significant linear relationship between $\mathrm{USV}_{12}$ and EBW, EB water, $\mathrm{CP}$, or lipid content $\left(\mathrm{r}^{2}=0.58,0.58,0.61\right.$, or 0.25$)$. The $\mathrm{r}^{2}$ value for the relationship of USV with CP content obtained in the present study was even greater than that reported by Jones et al. (1982) with nonpregnant and nonlactating dairy cows, although the relationship with fat content had a smaller $r^{2}$ value in the present study.

When predicting body composition in a linear relationship, LW was found to be a better predictor than USV in many studies. For example, the $r^{2}$ values were greater when using LW as a predictor, rather than USV, as reported in beef cattle (Rule et al., 1986; Hammond et al., 1988), Holstein steers (Hammond et al., 1990; 

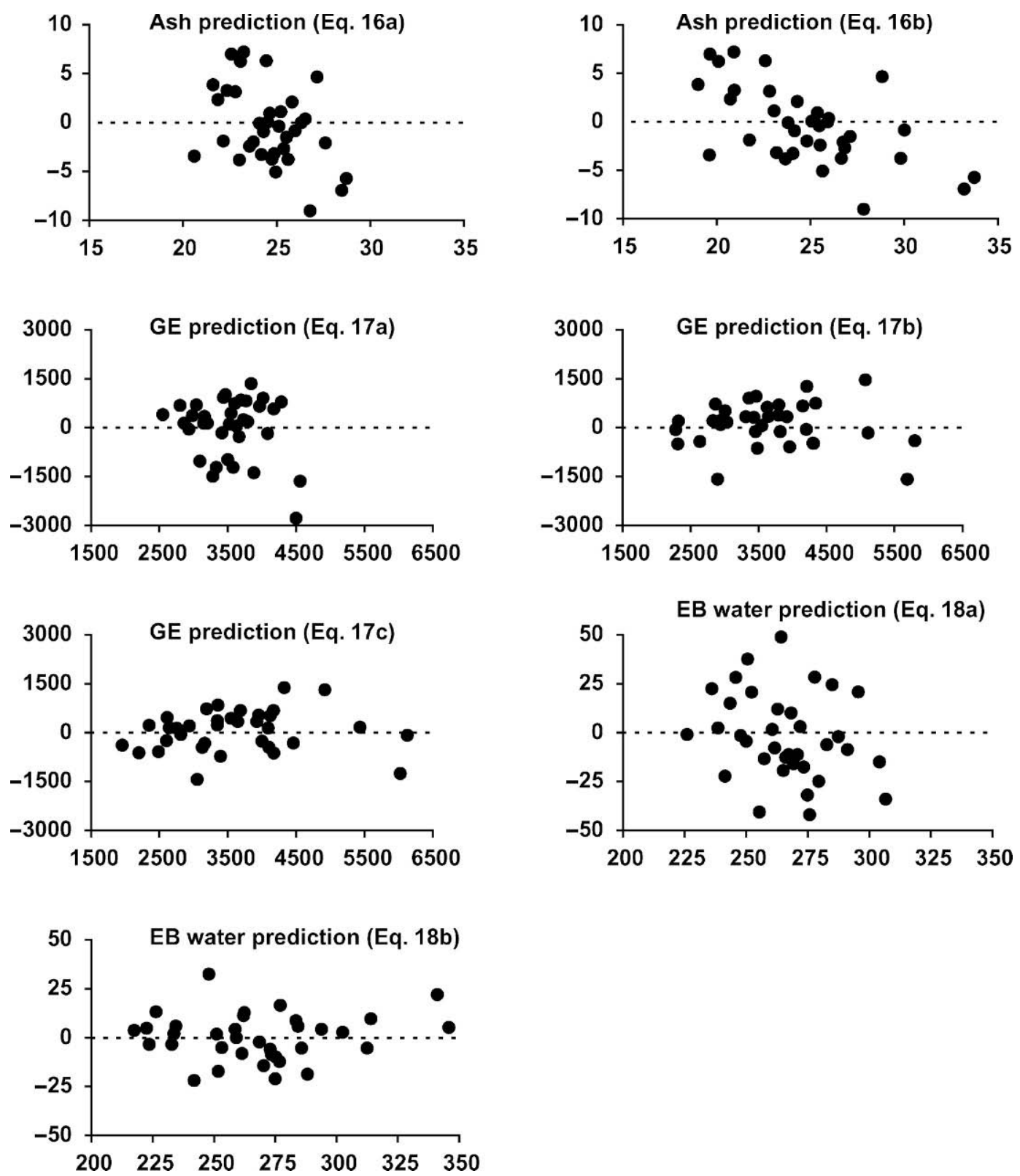

Figure 3. Predicted (x-axis) vs. residual (predicted - actual, y-axis) gross energy (GE, in MJ), ash, and empty body (EB) water (kg) contents. Internal evaluation of prediction equations developed from two-thirds of present data using one-third of the present data.

Velazco et al., 1997), nonpregnant and nonlactating dairy cows (Jones et al., 1982), and lactating dairy cows (Andrew et al., 1995). Similar results were observed in the present study (Table 2). However, when both $\mathrm{USV}_{12}$ (or $\mathrm{USV}_{12 / \mathrm{LW}}$ or $\mathrm{USV}_{12 / \mathrm{EBW}}$ ) and LW were used in multiple equations to predict body composition, we revealed an improvement in these relationships. For example, for prediction of EBW, CP, lipid, ash, energy, and EB water contents (equations [7a], [8], [9a], [10a], [11a], and [12]), the $\mathrm{r}^{2}$ values increased to $0.90,0.88,0.50$, $0.63,0.65$, and 0.83 and standard errors reduced to
$17.1,3.1,15.1,2.7,594$, and 11.8 , respectively. The improvement in $\mathrm{r}^{2}$ values, when using both USV and LW, rather than either alone, has been reported in previous studies (Rule et al., 1986; Hammond et al., 1988, 1990; Andrew et al., 1995). Therefore, adding USV as a predictor can improve the relationships between body composition and LW of cattle.

In the present study, the relationships for prediction of EBW, lipid, ash, and energy contents could be further improved when including milk yield or BCS, or both, or lactation number as supporting predictors to the 
equations using both $\mathrm{USV}_{12}$ (or $\mathrm{USV}_{12 / \mathrm{LW}}$ or $\mathrm{USV}_{12 / \mathrm{EBW}}$ ) and LW as predictors. It is logical that mature cows (3 or more lactations) would have a greater BW, and thus, greater ash contents compared with growing heifers. Therefore, addition of lactation number as a secondary predictor for prediction of ash content using $\mathrm{USV}_{12}$ and LW as predictors increased $\mathrm{r}^{2}$ values and reduced the standard errors (equation [10b] vs. [10a]). Normally, declining milk yield indicates advancing lactation. In late lactation, dairy cows retain nutrients in their bodies for the next lactation and the majority of nutrients are stored as fat. Declining milk yield, in association with greater BCS, would thus increase EBW, lipid, and energy contents. Including both milk yield and BCS as supporting predictors to the equations using USV and LW as predictors thus increased $\mathrm{r}^{2}$ values for prediction of EBW, lipid, and energy contents $(0.93,0.66$, and 0.77; equations [7d], [9d], and [11d], respectively). The corresponding standard errors were reduced to 16.2 , 12.6 , and 498 , respectively. The increase in $\mathrm{r}^{2}$ value by including milk yield and BCS as supporting predictors for EBW was marginal (0.90 vs. 0.93 ; equation [7a] vs. $[7 \mathrm{~d}])$, but substantial for prediction of contents of lipid ( 0.50 vs. 0.66 ; equation [9a] vs. [9d]) and energy (0.66 vs. 0.77; equation [11a] vs. [11d]).

\section{CONCLUSIONS}

Use of the urea dilution technique has the potential to estimate the body composition of lactating dairy cattle. The $\mathrm{USV}_{12}$ was related to EBW, EB water, CP, lipid, ash, and energy contents, whereas relationships for prediction of EBW and EB components using $\mathrm{USV}_{12}$ alone were poorer than that using LW. Using both USV and LW as predictors, however, rather than either alone, improved the relationships, $\mathrm{r}^{2}$ values being increased to $0.83,0.88$, and 0.63 for prediction of $\mathrm{EB}$ water, $\mathrm{CP}$, and ash contents (equations [12], [8], and [10a]), respectively. The further inclusion of milk yield and BCS as supporting predictors marginally increased the $r^{2}$ value for prediction of EBW (0.93; equation [7d]) and substantially for lipid and energy contents ( 0.66 and 0.77 ; equations [9d] and [11d], respectively). Compared with linear regression equations, multiple regression equations had a smaller standard error, thus giving a greater accuracy from less variation. Internal evaluation of onethird of the present data using equations developed from two-thirds of the present data indicated that using USV, live weight, and other live animal variables as predictors, rather than using USV alone, considerably improved the prediction accuracy. The accurate prediction of body composition, especially lean mass, in a live animal is a key factor to ensure accurate quantification of nutrient requirements for maintenance in diet formu- lation. Results of the present study demonstrate that use of the urea dilution technique as a supporting variable to LW can provide an accurate prediction of lean mass in lactating dairy cows.

\section{ACKNOWLEDGMENTS}

The authors thank their colleagues at the Agricultural Research Institute of Northern Ireland for collection of the data used in the present study.

\section{REFERENCES}

Agnew, R. E., and T. Yan. 2000. The impact of recent research on energy feeding systems for dairy cattle. Livest. Prod. Sci. 66:197-215.

Agricultural and Food Research Council. 1993. Energy and protein requirements of ruminants. CAB International, Wallingford, UK.

Andrew, S. M., R. A. Erdman, and D. R. Waldo. 1995. Prediction of body composition of dairy cows at three physiological stages from deuterium oxide and urea dilution. J. Dairy Sci. 78:1083-1095.

AOAC. 1996. Official Methods of Analysis. Association of Official Analytical Chemists, Washington, DC.

Bartle, S. J., S. W. Kock, R. L. Preston, T. L. Wheeler, and G. W. Davis. 1987. Validation of urea dilution to estimate in vivo body composition in cattle. J. Anim. Sci. 64:1024-1030.

Bartle, S. J., J. R. Males, and R. L. Preston. 1983. Evaluation of urea dilution as an estimator of body composition in mature cows. J. Anim. Sci. 56:410-417.

Bennett, G. L., L. A. Swiger, R. L. Preston, and V. R. Cahill. 1982. Evaluation of urea space and ultrasonic measurement as selection criteria for beef animal composition. J. Anim. Sci. 54:553-558.

Birnie, J. W. 1999. Factors influencing the fasting heat production of non-lactating dairy cattle. Ph.D. Thesis, The Queen's Univ. Belfast, Belfast, UK.

Bligh, L. G., and W. J. Dyer. 1959. A rapid method of total lipid extraction and purification. Can. J. Biochem. Physiol. 37:911-917.

Brouwer, E. 1965. Report of sub-committee on constants and factors. Pages 441-443 in Energy Metabolism: Proc. 3rd Symp. European Assoc. Anim. Prod. Publ. No. 11, K. L. Blaxter, ed. Academic Press, London, UK.

Hammond, A. C., T. S. Rumsey, and G. L. Haaland. 1984. Estimation of empty body water in steers by urea dilution. Growth 48:29-34.

Hammond, A. C., T. S. Rumsey, and G. L. Haaland. 1988. Prediction of empty body components in steers by urea dilution. J. Anim. Sci. 66:354-360.

Hammond, A. C., D. R. Waldo, and T. S. Rumsey. 1990. Prediction of body composition in Holstein steers using urea space. J. Dairy Sci. 73:3141-3145.

Jones, S. D. M., J. S. Walton, J. W. Wilton, and J. E. Szkotnicki. 1982. The use of urea dilution and ultrasonic backfat thickness to predict the carcass composition of live lambs and cattle. Can. J. Anim. Sci. 62:371-379.

Kock, S. W., and R. L. Preston. 1979. Estimation of bovine carcass composition by the urea dilution technique. J. Anim. Sci. 48:319-327.

Marsh, W. H., B. Fingerhut, and H. Miller. 1965. Automated and manual direct methods for the determination of blood urea. Clin. Chem. 11:624.

Meissner, H. H., J. H. van Staden, and E. Pretorius. 1980. In vivo estimation of body composition in cattle with tritium and urea dilution. 1. Accuracy of prediction equations for the whole body. S. Afr. J. Anim. Sci. 10:165-173.

Mulvenny, P. M. 1977. Dairy cow condition scoring. Natl. Inst. Res. Dairying, paper 4468, Reading, UK.

National Research Council. 2001. Nutrient Requirements of Dairy Cattle. 7th rev. ed., Natl. Acad. Sci., Washington, DC. 
Porter, M. G. 1992. Comparison of sample preparation methods for the determination of the grass energy concentration of fresh silage. Anim. Feed Sci. Technol. 37:202-218.

Preston, R. L., and S. W. Kock. 1973. In vivo prediction of body composition in cattle from urea space measurements. Proc. Soc. Exp. Biol. Med. 143:1057-1061.

Reid, J. T., G. H. Welington, and H. O. Dunn. 1955. Some relationships among the major chemical components of the bovine body and their application to nutritional investigations. J. Dairy Sci. 38:1344.

Rook, A. J., M. S. Dhanoa, and M. Gill. 1990. Prediction of the voluntary intake of grass silages by beef cattle. 3 . Precision of alternative prediction models. Anim. Prod. 50:455-466.

Rule, D. C., R. N. Arnold, E. J. Hentges, and D. C. Beitz. 1986. Evaluation of urea dilution as a technique for estimating body composition of beef steers in vivo: Validation of published equations and comparison with chemical composition J. Anim. Sci. 63:1935-1948.

San Pietro, A., and D. Rittenberg. 1953. A study of the rate of protein synthesis in humans. 1. Measurement of the urea pool and urea space. J. Biol. Chem. 201:445.

Velazco, J., J. L. Morrill, D. H. Kropf, R. T. Brandt, Jr., D. L. Harmon, R. L. Preston, and R. Clarenburg. 1997. The use of urea dilution for estimation of carcass composition of Holstein steers at 3,6, 9 and 12 months of age. J. Anim. Sci. 75:139-147.

Wells, R. S., and R. L. Preston. 1998. Effects of repeated urea dilution measurement on feedlot performance and consistency of estimated body composition in steers of different breed types. J. Anim. Sci. 76:2799-2804 